\title{
MOVING MOUNTAINS IN THE INTERCULTURAL CLASSROOM
}

\author{
Vivian Faith Martindale \\ University of Alaska S.E.
}

Today many Alaska Natives are seeking a higher education; however due to subtle differences in communication styles between the Native Alaskan student and Euro-American instructor, both students and educator frequently experience communication difficulties. This paper examines the differences in non-verbal communication, the assumption of similarities, stereotyping, preconceptions, and misinterpretations that may occur between Alaska Native and Euro-American cultures. University classrooms are becoming increasingly multicultural, and one teaching style may not be effective with all students. Those involved with education need to promote flexibility and awareness of cultural differences in order to achieve successful communication in the classroom.

The communication styles of the Alaska Native culture and 
the Euro-American culture are very different; therefore, teaching college in Alaska can be a challenge for educators. Certain aspects of the Alaska Native culture, although some may seem insignificant, can become obstacles to effective intercultural communication. Removing the obstacles that exist between the Alaska Native culture and the Euro-American culture can seem like moving mountains. The most important place to begin removing obstacles is with an understanding of the basic differences in the Alaska Native culture versus the Euro-American culture, among which are the Alaska Native worldview, including the languages, and differences in non-verbal communication. The differences in non-verbal communication include face-saving techniques, body language, implied meanings, pauses and silence. The assumption of similarities must be addressed, as well as stereotyping, preconceptions, and misinterpretations. The obstacles must be examined and understood in order to be an effective educator among Alaska Native students. After all, without effective communication, effective education cannot occur.

The first problem lies with assuming similarities. EuroAmericans tend to expect similarities between their culture and the culture of another. According to Laray M Barna in "Stumbling Blocks in Intercultural Communication" this "confidence comes from a myth of similarities, which is much stronger than assuming differences between cultures"(337). It is easy for educators to assume that because there are similarities between Alaska Native culture and Euro-American culture, there will not be a breakdown in communication. For instance, a common concept is assuming that Euro-American and Alaska Native cultures are similar because looking around small Alaskan towns, we see Natives living like everyone else. Some are teachers, bus drivers, policemen, secretaries, fisherman, etc.; therefore we are assuming similarities. This tendency to assume likeness occurs because it makes communication easier, but in actuality, it hinders it. It makes people uneasy to deal with differences. Realizing there are assumptions of similarity being made is the first step towards removing the obstacles.

The second obstacle is understanding the Alaska Native worldview in which the Natives languages are connected. In Alaska, as it is with a majority of colleges in the United States, 


\section{Ethnic Studies Review Volume 25}

college instruction is in English, and since most Natives speak English as their first language, a language barrier is not a problem during communication between Native students and their instructors. However, the concepts in the Alaska Native worldview, which include their ancestral language, may be a hindrance to effective communication. The Alaska Native worldview consists of many dimensions. The Alaska Native worldview is the Alaska Native culture, and it is handed down from generation to generation. In Haa Kusteeyí Tlingit author Nora Dauenhauer writes, "The way we speak to our elders, how we interact with one another, family ties, and subsistence lifestyle, all are a part of our worldview" (15). To simplify, Alaska Natives view this world and react to it in a different manner from EuroAmericans. If an instructor assumes that all his or her students are communicating in the western worldview, then the instructor is making the first mistake (Barna 337). For Alaska Native students, existing in western society with the worldview of their culture poses everyday challenges, especially when a Native student decides to seek a western college education. For an educator, understanding that despite the fact that Alaska Natives speak English, their worldview is very different from the EuroAmerican's is essential to communication with Alaska Native students.

Traditionally, in the Tlingit culture, as well as other Alaska Native cultures, education was not an institutional matter. Education was the responsibility of the child's family. In the Tlingit worldview, one never stops learning, and the family and the community are the classrooms. Young people are taught by their elders and specifically by their mother's brother. Native children are taught to respect elders, never interrupt, and learn by observation (Dauenhauer 20). Some of these important aspects of their earlier learning are not always applicable to the college setting. For example, Alaska Native people see themselves as a part of a cultural group, a concept that goes against the grain of the independent " $\mathrm{I}$ " concept of Euro-Americans. For many Native students making the transition from a traditional athome-family educational settin, to a classroom education and then going onto college is quite the undertaking. Carol Williams, Title 9 grant coordinator for the Hoonah School District and 
University of Alaska Community Schools Representative, in an interview (Nov. 14, 2001) stated the following:

I was resistant when the school district wanted to teach our culture in the classroom. We learned about our culture at our grandparents' knees. We listened and learned. We watched and learned. Eventually, I realized that we were losing something if we did not teach others the important parts of our culture, like the language. Many parts of our culture would be lost on the upcoming generations.

Williams, as well as other Tlingit educators, were reluctant to make the change from the traditional family learning environment to the public setting. To move from the traditional Native educational style of watching and observing to the EuroAmerican practice of interrupting and asking questions is difficult for many Alaska Native students, thus creating another obstacle in communication.

Native students have a difficult time interrupting the instructor to ask questions. Williams said that if she participated in a class with twenty-five other classmates, "I would not interrupt them and would probably remain silent." Williams said that it is very hard for Native students to interrupt because they are taught that the speaker's words are as important as theirs. "If I interrupted the teacher I would make them feel less important." Alaska Natives place a great importance on a speaker's abilities and their oral traditions that are handed down from generation to generation. She explained that interrupting in a classroom setting is very hard because "it is important for us to confirm to the teacher that we knew the answer; however, this is difficult because we do not interrupt, and we take longer to answer the question." This is a face saving technique used by Alaska Native cultures. The Native student does not want the teacher to feel unimportant nor does the Native student want to be perceived as being rude or inconsiderate. This inability to interrupt is a facesaving measure that is often unrealized during the communication between the Euro-American educator and the Native student and must be taken into consideration when teaching in a multi-cultural classroom.

Saving face and misinterpretations of non-verbal language 


\section{Ethnic Studies Review Volume 25}

often happen between the Alaska Native student and the EuroAmerican educator during the beginning of a class, at the time of introduction. Because people either approve or disapprove of initial interactions with one another, educators often evaluate "the statements and actions of the other person or group rather than to try to comprehend completely the thoughts and feelings expressed from the worldview of the other" (Barna 342). According to the video, Talking Alaska: Intercultural Communication, when Native people meet new people, Natives often remain quiet and get to know each other using non-verbal language before beginning the conversation. The person from the Euro-American culture likes to ask questions and begins the conversation right away in order to get acquainted. The EuroAmerican will often speak openly about himself revealing information that a Native person would not. In Alaska Native cultures it is not polite to talk about yourself. This difference can be a hindrance for Alaska Native students because it will take them longer to feel comfortable in expressing themselves in the classroom setting.

Nonverbal communication is often misunderstood among participants in an intercultural classroom. Alaska Natives are less likely to be dramatic in their arm and body movements and may make less direct eye contact than European Americans. Williams said, "As young children, we are taught not to make direct eye contact unless instructed to do so by an elder when the elder is speaking specifically to the child."

When a Native student does not look the educator in the eye and avoids direct contact this can lead to assumptions that the student may not be paying attention or is being shy. Misinterpretations can lead to the tendency to evaluate a culture based on assumptions, not knowledge of the culture. In Managing Intercultural Conflicts Effectively, Stella Ting-Toomey suggests that during a conversation the speaker and the listener may be making false assumptions, such as the other person is offensive, rude, or shy, or many other labels that one can attach to a miscommunication (364). If a miscommunication occurs, the educator needs to accept that the Native student did not intend to confuse information or to convey negative attitudes, through the use of body language or long pauses. Recognizing 
the indirect eye contact a Native person may exhibit during a conversation as a sign of respect, rather than shyness, is essential to effective communication between an educator and student.

Another nonverbal misinterpretation is the difference in the time that traditionally occurs between a Native speaker's statement and a Native listener's response. Native speakers will likely pause by way of exhibiting not only respect but also thoughtfulness, while a non-Native speaker tends to seek to respond immediately to demonstrate command of knowledge or quickness of mind. Though only seconds occur between the question and the response, in the western classroom environment those seconds are enough to make the Euro-American educator ask another student the same question, assuming the Native student does not know the answer. Also because the Alaska Native student is quiet following a statement does not mean that the student understood the message. These subtle but complex differences can be hindering when it comes to conversation and classroom interaction. People from individualistic cultures such as the Euro-American culture, whose focus comes from the individualistic mindset, should seek to become aware of the face-saving characteristics of collective cultures like that of Alaska Natives. Direct confrontation is avoided and silence is observed out of respect and as a sign of reflectiveness, also as a sign of respect for the words and thoughts of another, particularly an elder.

Educators must realize that if they do not call on the Native student, the student may not say anything during the entire class. Raising one's hand, waiting one's turn to speak, and interrupting to ask questions can all pose challenges for Native students in a classroom. It takes a conscious effort on the part of the Native student to become accustomed to the classroom protocol. In the interview mentioned above, Carol Williams said: "We don't ask questions because we are expected to grasp the meaning with our own mind. An elder will tell you that the answer will come to you. We train our children to use their minds." According to Williams when a question is asked and the answer is very apparent, Native speakers do not want to embarrass the teacher by answering the question. They also are thinking about what the teacher is really asking.

When a teacher asks a question, we will think about it, 
ponder it, and give an answer using the right words.

We may not be ready to answer the question for ten or fifteen minutes"(Williams).

The educator must be aware of the importance of words in the Alaska Native culture and the difficulty the Native student may have in immediately addressing a question.

This difficulty in choosing the right words to answer a question comes from there being implied meanings in Alaska Native culture. The Alaska Native culture is considered a "high context" culture. According to Edward T. Hall, this type of classification examines the relationship between what is implied in communication and what is stated outright. European American culture tends to be low context, meaning that Americans tend to be more precise in their verbal communication. Meaning is implied or presumed in Alaska Native culture (Ting-Toomey 362). Silence is an example of an implied meaning. In Alaska Native culture, silence is a sign of respect. A Native student who does not speak out in school has been taught that to do so is impolite because a listener is as respected as a speaker is. In the low context European American culture, if one does not speak out then the person must agree with whatever is being said, whereas in Alaska Native culture, people value what the person is saying whether it is right or wrong. A communication breakdown can occur when the Euro-American educator is trying to teach from a low context point of view where everything is transmitted in a "pattern of linear logic and direct verbal interaction style" (TingToomey 362). The Euro-American communication style can seem overwhelming to a Native student trying to interpret the applied meaning in the conversation.

Not understanding the behavior of others during conversation leads to frustration, and frustration leads to stereotyping. According to Ron Scollon in Interethnic Communication, "We unconsciously feel that our own way of communicating is natural and correct and that any deviation from this style is unusual or strange" (59).

Educators who misunderstand the important aspects of silence and pauses in Alaska Native culture may assume the student is unfocused or lazy. With regard to Euro-American stereotyping, all too often are heard statements like "They are so slow" 
and expressions of prejudiced attitudes like "Natives are dumb." These stereotypes evolve from the misinterpretation of silence in a conversation and the difference in the time between questions and answers. According to Carol Williams, a Native person may take as much as ten seconds longer than a Euro-American to answer a question. She said that the longer pauses are due to the view that every word a Native person uses should be chosen very carefully because Natives are cultural thinkers; "When we are thinking about how to answer a question, we are also thinking about how this will impact our culture." The instructor needs to have patience, avoid stereotyping, and understand that there will likely be longer pauses when a Native student is considering how to answer the question.

Another difference in culture is the Euro-American obsession with time and the Alaska Native sense of time. According to Intercultural Competence: Interpersonal Communication Across Cultures, authors Myron Lustig and Jolene Koester, orientation to time is a cultural pattern that "concerns how people conceptualize time" (100). Euro-Americans are obsessed by time. In contrast, in Alaska Native cultures, time is viewed in a very different context. The measurement of time is part of the Tlingit worldview. Time is tied to the seasons, to fishing and hunting, and to the moon; hence, time is variable, not linear and constant. In Native culture, things begin when everyone important arrives which may not be at the set time of the particular event. This has lead to the Euro-American stereotypical saying: "Indian Time." Native culture does not have the same sense of "being on time," or the obsession with it that Euro-American culture does. Therefore, the educator needs to be aware of this difference and be patient with his or her student, respecting the Native sense of time as a part of their worldview.

The Alaska Native's sense of time can affect classroom attendance and promptness, which are highly valued by EuroAmerican culture. In my interview with Carol Williams, she also said that there is some truth to the phrase "Indian time," although she added that the term is often used in a derogatory manner. Williams said she finally stopped wearing her watch because it was always a reminder that she was late for something. She said that Native students are often late for appointments because 


\section{Ethnic Studies Review Volume 25}

Natives are cultural thinkers, not thinking about "I'd better hurry because I'm going to be late" or "I have an appointment at such and such a time." She said that whatever is going on at the time prior to the engagement receives the complete focus of the Native person. Williams added, "It is impolite to rush someone and we will give whatever we are doing at that moment our time."

Natives will arrive at the next appointment when it is their time to arrive. As a consequence, a student may consistently arrive at a college classroom a few minutes late, having no concept that the educator may expect that everyone be there early for attendance taking. The educator must understand it is possible for two cultures, like the Euro-American culture and the Alaska Native culture, to exist side by side and have two totally different senses of time.

As with the Alaska Native concept of time, the Native culture has a different style in presenting its ideas. The Tlingit culture is more analogical than Euro-American culture. With this type of communication style there is an implied or explicit lesson, story or analogy, which the speaker uses to persuade the listener (Lustig 224). This approach is evident in the stories prevalent in the Tlingit culture. For example, Williams described the concept of the importance of words in a teaching parable her father told her as a child. He said whenever she spoke, to imagine herself in a crowded room with a ten-foot stick. The stick was a symbol for her words, and if she turned the wrong way or misspoke she could hurt someone. He cautioned her to be very careful because the hurt that words cause cannot be undone. This illustrates the value that Alaska Native culture puts on the speaker, stemming from the importance placed upon the oral tradition. A Native student may use this presentation style in the classroom, causing some educators to become impatient as it may take the student longer to make their point than EuroAmerican students. Specifically, educators should allow extra time for the student to speak, not interrupt the Native student, and listen until they are finished.

Because the communication styles of the Euro-American educator and the Alaska Native student are different, the educator should be aware of assuming similarities and resist making 
false assumptions. Learning about the worldview differences and avoiding stereotypes are important steps in the right direction to effective intercultural communication, making it easier for Native students to express themselves in a classroom setting. It is the responsibility of the educator to take the time to listen, show interest, thoughtfulness, and empathy in order to remove the obstacles of ineffective communication. According to the Bible, "If you have faith as a mustard seed, you shall say to this mountain, "Move from here to there and it shall move" ("Matthew" 17:20).

Stumbling blocks to communication can, when piled together, be as big as a mountain, yet even if we have the faith that the obstacles can be removed, they may not move out of the way so easily. It takes an active participant and a conscious effort to communicate effectively between student and educator. One by one, if we remove the obstacles that build that mountain of massive miscommunication, we can move it. Moving the mountains blocking our effectiveness as a communicator can make for a successful college experience for Alaska Native students.

\section{Works Cited}

Barna, Laray M. "Stumbling Blocks in Intercultural Communication." Intercultural Communication: A Reader. 7th ed. Eds. Porter, Richard E., Larry A. Samovar. Belmont: Wadsworth, 1997. 337-44.

Dauenhauer, Nora Marks and Richard. Haa Kusteeyi, Our Culture: Tlingit Life Stories. Seattle: University of Washington Press, 1994.

Lustig, Myron W., Jolene Koester. Intercultural Competence: Interpersonal Communication Across Cultures. NY: Addison Wesley, 1999.

Scollon, Ron, Suzanne B.K. Interethnic Communication. Fairbanks: University of Alaska, 1980.

Talking Alaska. Dir. Carol Bain. Videocassette. University of Fairbanks: Alaska Native Language Center, 1989. 
Ting-Toomey, Stella. "Managing Intercultural Conflicts Effectively." Intercultural Communication: A Reader. 7th ed. Eds. Porter, Richard E., Larry A Samovar. Belmont: Wadsworth, 1999. 362-64.

\section{BOOK REVIEWS}

\section{Jane M. Gaines, Fire and Desire: Mixed-Race Movies in the Silent Era (Chicago: University of Chicago Press, 2001) 359 pp., \$19.}

Jane M.Gaines has written an important book on the topic of race movies and race relations in early American cinema. Using eclectic analyses that range from W.E.B. DuBois' insights on "double consciousness," to queer theory, Gaines is able to critically examine issues of mixed race people and race mixing in silent films. She wonderfully reworks some theories until they yield beneficial interpretations. For example, Gaines argues against the blanket use of psychoanalysis as a tool to comprehend African American Experience, including cinema, because, she says, "Historically psychoanalysis had no cognizance of black people nor was any attempt made to understand them" (75). According to her film theory has been exclusively psychoanalytic in recent years to the exclusion of almost any other alter- 